\title{
Ensuring Effective Public Service Delivery in the Field Administration of Bangladesh to Boast up Good Governance: The Perspective of Deputy Commissioner Office
}

\author{
Mohammad Saiful Hassan ${ }^{1,2}$ \\ ${ }^{1}$ Graduate School of Economics, Yamaguchi University, Yamaguchi, Japan \\ ${ }^{2}$ Ministry of Public Administration, Government of the People's Republic of Bangladesh, Dhaka, Bangladesh \\ Correspondence: Mohammad Saiful Hassan, Upazila Nirbahi Officer, Divisional Commissioner Office, Rajshahi, \\ Bangladesh. Tel: 880-1191-109545. E-mail: saiful15701@yahoo.com
}

Received: February 9, 2015

Accepted: February 25, 2015

Online Published: March 27, 2015

doi:10.5539/ijbm.v10n4p92

URL: http://dx.doi.org/10.5539/ijbm.v10n4p92

\begin{abstract}
Good governance is an ideal concept which is very much important for achieving socio-economic development of a country. Effective public service delivery is an important instrument for boasting up the good governance. Unfortunately, the public sector in Bangladesh does not often function according to citizen's expectations. Citizens are very much dissatisfied with the public service delivery system. World Bank, International Monetary Fund (IMF) and donor nations are urging Bangladesh to ensure public services to citizen. Surprisingly, except only a few initiatives such as, introducing charter of duties, enactment of Right to Information Act 2009, the matter of improving public service delivery remained untouched in the field administration of Bangladesh. Therefore, it becomes eminent and most essential to ensure timely and corruption free public service delivery for citizens. Through this research a Strategic and Tactical Systems Level Framework and Model of Effective Public Service Delivery has been developed with the comparison of applying benchmark framework to Bangladesh experience as in the case of Deputy Commissioner Office. Research evidences provided in literature review, international experiences and case study analysis have been used as the basis for developing the benchmark framework. The model can be effective in ensuring public service delivery and updating the status of customer satisfaction which will ultimately reflect the good governance policy to be implemented, maintained and sustained.
\end{abstract}

Keywords: public service, good governance, field administration, district commissioner, strategic and tactical systems level framework and model of effective public service delivery

\section{Introduction}

Good governance is an ideal concept which is quite difficult to achieve in its totality for a third world country. This form of governance system exists in the first world countries like the USA, Japan, the UK, Australia and France. In today's open market economy, a developing country like Bangladesh is facing tremendous obstacles in attaining socio-economic growth due to the absence of good governance. Recently, the World Bank, the International Monetary Fund (IMF) and the donor nations are urging Bangladesh to establish good governance systems in all aspects of the government. As a result, Bangladesh government and the key think tankers feel that public administration is one of the most important government apparatus through which good governance can be implemented, maintained, and sustained. The field administration shall be the starting point of such an initiative. As a pivot of the district administration, Deputy Commissioner Office can be the best choice to experiment the idea.

Because of the importance of the DC office, the government has taken various measures to ensure timely and corruption free public services for citizens. Charters of duties, massive transfer to officials, frequency inspection, report return, punishment to corrupted officials, enactment of Right to Information Act 2009, introducing e-governance and performance measurement system, for examples, are important initiatives to be mentioned. Despite the aforementioned initiatives, quality of services was not achieved at its desired level. According to the survey report of World Bank and others (2002), "less than $28 \%$ of the households are satisfied with the education system, $18 \%$ with the quality of health care, $12 \%$ with the electricity service, $11 \%$ with the quality of drinking 
water, $17 \%$ with the quality of sanitation, $20 \%$ with the transport services, $2 \%$ with the police service, $8 \%$ with the judicial service and $10 \%$ with the land services". In the rural area, this condition is very alarming. Poor people are deprived from getting their desired services from the government offices. As a pivot of the district administration, it is the sole responsibility of the Deputy Commission to ensure quality public service to citizens.

This research will aim to find out solutions for introducing a new mechanism for DC office in ensuring effective public service delivery and refer the idea to implement in other public offices of the field administration of Bangladesh.

The study is scripted in six chapters. The introductory chapter comprises the background and overview of the study; chapter 2 draws upon an extensive review of literature; chapter 3 describes on the public service delivery in the field administration of Bangladesh; chapter 4 reviews on different approaches adopted by different countries in ensuring effective public service delivery; chapter 5 contains the case study analysis of the Yamaguchi City Hal, Japan to evaluate the significant efforts in ensuring effective public service delivery within its real-life context and the final chapter draws upon the findings, analysis and conclusion.

\subsection{Objectives of the Study}

This study attempts to explore a strategic and tactical systems level framework and model of effective public service delivery to be used in the DC office to ensure effective public service delivery and then tries to identify its implications for future practices to ensure effective public service delivery in the field administration of Bangladesh.

\subsection{Research Methodology}

The research methodology is qualitative in nature. A background of the research has been reviewed to approach the problem. Depending on the theoretical analysis a conceptual framework has been developed to support the background research findings. Five countries have been selected to have background knowledge of international experience. Those countries have been selected on the basis of success in reform initiatives they took in ensuring public service delivery and in satisfying the customer as well as achieving good governance. Data has been collected from secondary sources such as books, reference journals, seminar and working papers, local and foreign articles, national and international newspaper and websites of related organizations. A case study method has been used to investigate a phenomenon of the research problem within its real-life context. Case study has been analyzed depending on both the primary and secondary data. Open ended questionnaire was developed to conduct a direct interview. A non-probability sampling technique has been used to approach the case study. A methodological framework and model has been developed with the comparison of applying benchmark framework to Bangladesh experience.

\section{Literature Review}

\subsection{Concept of Good Governance}

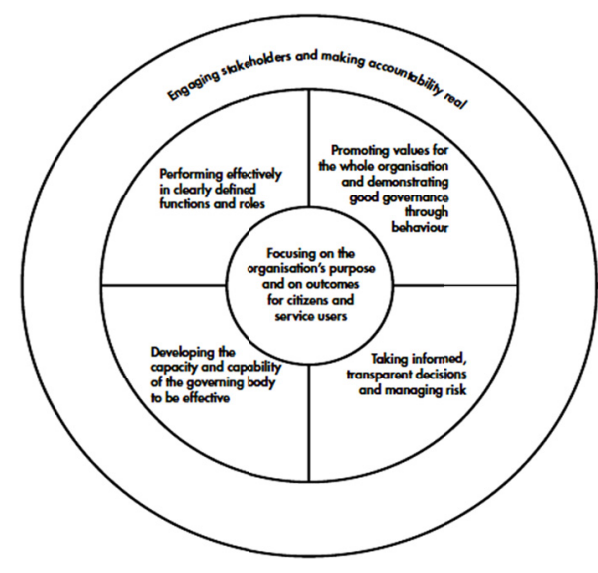

Figure 1. Principles of good governance

Source: the Independent Commission on Good Governance in Public Services (2005), UK.

From the late 1980s, the debate on good governance and its requirements provides an impetus for new approaches to public sector management reforms. Because it encourages the public trust and participation that 
enables service to improve; bad governance fosters the low morale and adversarial relationships that lead to poor performance or even, ultimately, to dysfunctional organizations (Independent Commission of the UK, 2005). World Bank (1989) defines good governance as, an efficient public service; an independent judicial system and legal framework to enforce contracts; accountable administration of public funds; an independent public auditor, responsible to a representative legislature; respect for the law and human rights at all levels of government; a pluralistic institution structure and; a free press.

There is no any common code for public service governance that will guide the public services in the complex and diverse world. But the government can set up some standard of public services that can guide the civil service management.

According to the Report of the Independent Commission on Good Governance in Public Services, UK (2005), good governance standard has 6 principles, as shown in figure 3. According to Obaidullad (2001), "it is the efficiency and effectiveness of the administrative organ of the government in the delivery of services that makes a significant difference between good and bad government". Thus, ensuring effective service delivery in the public sectors will boast up the good governance which is the main theme of this paper.

\subsection{Mainstreaming Public Service Values}

Pettigrew's model of strategic change (1988) as shown in figure 4, suggests context, content and process as the three important elements of exploring the issue of mainstreaming the customer service values in an organization. A brief discussion on the changes in public service delivery is discussed below using Pettigrew model as the key concept.

\subsubsection{Context for Change in Public Service Delivery}

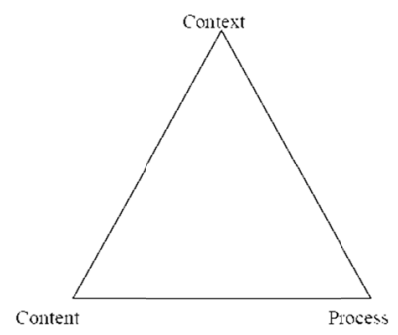

Figure 2. Model of strategic change

Source: Pettigrew (1998).

In this part, why public organizations are undergoing change in relation to effective public service delivery has been reviewed. According to Tamraka (2010) "public services should be concerned with what the customer wants rather than with what providers are prepared to give. In general, public servants have not acted as servants of people but rather as masters without any sense of accountability and transparency. People are unaware of how and where to obtain public services and often become the victim of middle man or corruption. Cumbersome procedure, slow pace of decision making and service delivery cause suffering to people and waste their money and time".

As a result, citizens become frustrated and dissatisfied towards government. In this situation, there is a need for ensuring delivery of public services that can satisfy the need of the citizens. However, there is no one best approaches that can be applied to ensure effective public service delivery. Different countries have different reform initiatives as shown in chapter 4. 


\subsubsection{Content for Change in Public Service Delivery}

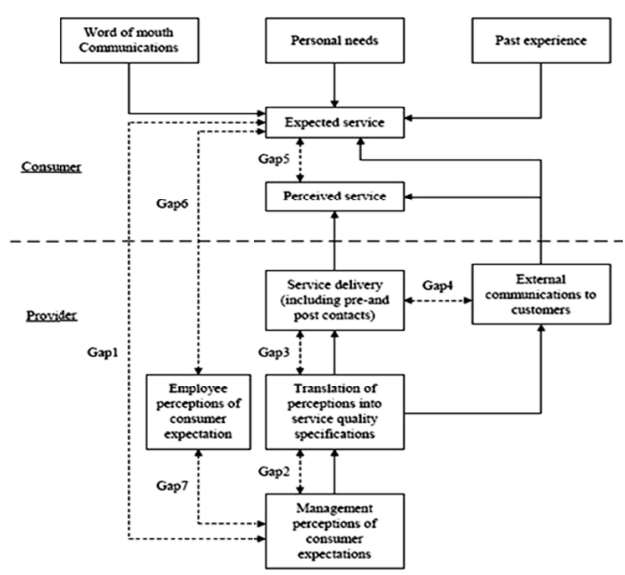

Figure 3. Model of service quality gap

Source: Parasuraman (1985); Curry (1999), Luk and Layton (2002).

What a public service ethos entails is examined in this section. Two research approaches are reviewed to identify the different perspectives of service and service quality.

\subsubsection{Expectation-Perception Approach to Quality Public Service}

A public organization can identify the gap between citizen's expectation and perception to improve the quality of public service. Parasuraman et al. (1985), based on gap analysis, has developed a service quality model, as shown in Figure 5.

The model identifies seven key gaps relating to managerial perceptions of service quality, and tasks associated with service delivery to customers. The first six gaps (Gap 1, Gap 2, Gap 3, Gap 4, Gap 6 and Gap 7) are identified as functions of the way in which service is delivered, whereas Gap 5 pertains to the customer and as such is considered to be the true measure of service quality.

The USA, the UK, Australia, Ireland, Malaysia and Japan, for examples, already have introduced the mechanism of consulting with customers, employees and stakeholders in determining and improving service standard and established complaints and feedback procedures in dealing with the customer's expectation that can be satisfied by ensuring values as standard.

\subsubsection{Core Value (Guiding Principles) Approach to Quality Public Service}

An organization can also improve the core value in service delivery. OECD (1996) and Gaster (1995) that have identified core elements of effective service delivery to customers are: reliability (service dependability); responsiveness (willingness to help customers); assurance (courtesy, trust and confidence); empathy (understanding of the customer's needs); and tangibles (physical environment of the service provider). Below are the two practical examples of applying core value approach to improve quality of public service:

In Indonesia, Ministry of State Apparatus Reform (2003) drew up following fifteen criteria as the general guidance for quality public service delivery and implementation: "Simplicity, Reliability, Responsibility, Capability, Closeness to the customer, Kindness and patience, Transparency, Communicativeness, Credibility, Clarity and certainty, Security, Understanding what customer expect, Reality, Efficiency and Economic".

In Ireland, each department/office of the government has successfully published a two-year customer service plan in 1997/98 focusing on core value approach to ensure the quality public service delivery (see more in chapter 4).

\subsubsection{Process Issue of Public Service Delivery}

In this section, how the public organizations adopt efficient public services is reviewed. Different approaches and guiding principles to effective public service delivery can be implemented through the use of effective processes and tools.

OECD (1996) that identified quality improvement tools to public service delivery are: Decentralization of decision making (see application in chapter 5); Separation of policy-making/service delivery in support of this 
approach (see application in chapter 4 and 5); Business process re-engineering (see application in chapter 4); Total Quality Management (see application in chapter 4); Small scale change projects (see PMS in chapter 3). Recently, OECD research (1998) added two more tools to enhance the service delivery mechanism in public sector. Those are charters (see in chapter $3 \& 4$ ) and performance measurement (see in chapter 3, 4 and 5).

Kristi M. Branch (2002) complied an overview of tools and approaches from the writings of Jacobs (1994), Mohrman and Mohrman, Jr. (1993), Miles (1997), and Nadler and Tushman (1997) as follows: Backward Mapping approach; Balanced Score card approach; Benchmarking approach; Business Process Reengineering; Continuous Improvement in performance and customer satisfaction; Cultural Change, Employee Involvement; ISO9000 standards of performance and quality; Knowledge Management; Learning Organization to increase capacity for performance; Management by Objectives; Organizational re-design to build new, more appropriate capabilities and processes; Outcome-Based Evaluation; Total Quality Management (TQM);

Giving importance on NPM, Gaster (1995), Beer et al (1990) suggest the pilot change programs as a means of gaining support for service quality change. Gaster's (1995) adds the involvement of front-line staff as a key factor in the success of a quality initiative change program and give importance on the internal customer service. Bangladesh has introduced PMS as a pilot basis in seven districts of the country. On the other hand, Malaysia and USA have introduced rewards and recognition system in public offices to motivate internal customers.

Alongside these tools many service quality improvement models have been developed to expertise the process of effective customer service delivery. Few of them are discussed below:

European Foundation for Quality Management Model (EFQM):

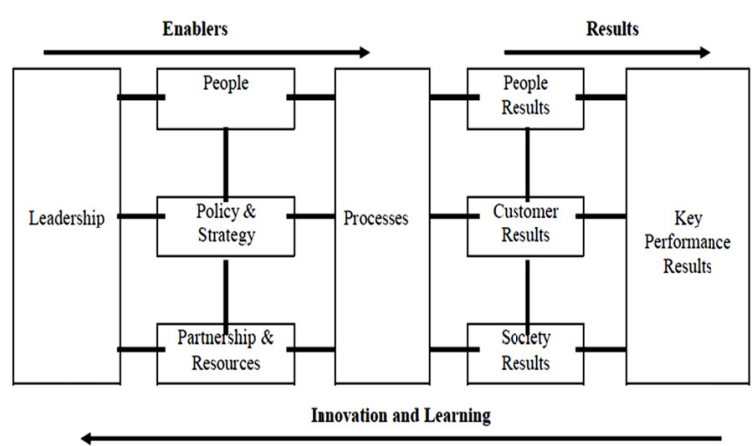

Figure 4. EFQM excellence model (1999)

Source: http://www.efqm.org.

European Foundation for Quality Management's (EFQM) Model for business excellence assumes that service measures such as customer results, people results and society results, are achieved through leadership (which drives the policy and strategy), good HRM, resource and processes, lead to excellence in key performance results (Humphreys et al., 2000). This model suggests incorporating the needs and input of a wide range of stakeholders including customers, employees and other group within the local or national community. Schlesinger and Heskett (1991) states that, "An organization having strategic recruitment and training policies and broad description can lead to a cycle of success and as a means of enjoying employee's greater empowerment and satisfaction and ultimately ensuring better customer service."

The UK (see in chapter 4) and the Yamaguchi City Hall, Japan, for example, (see in Chapter 5) have adopted this model by engaging civil society and customer for identifying customer needs and managing customer service and did success. On the other hand, The USA and Malaysia, for example, have taken many reform initiatives to motivate employees by measuring and recognizing their performance (see in chapter 4).

Service Quality model given by Adrienne Curry, Wilma Lyon, (2008):

Adrienne Curry, Wilma Lyon, (2008) has proposed the model, as shown in figure 7, for generalized use in both the public and private sectors. This model was developed for Starling Council call centre, UK. 


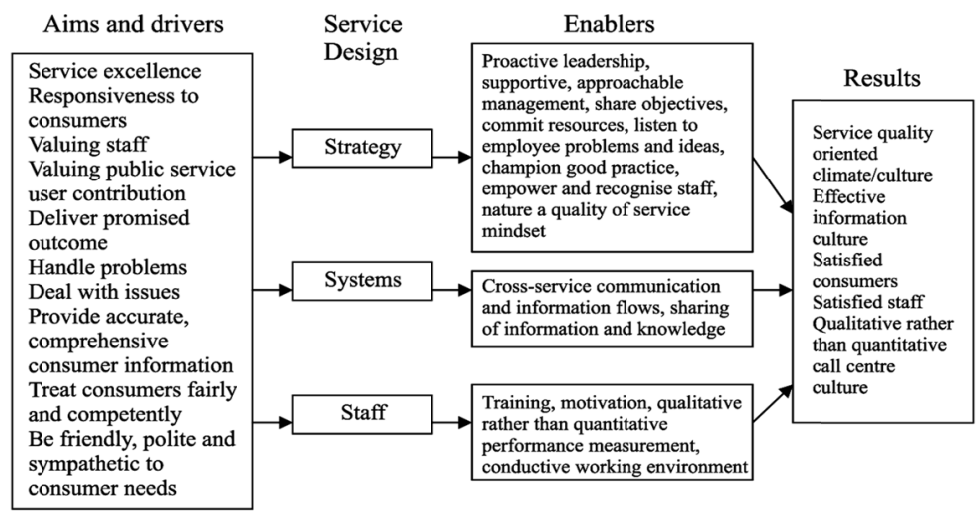

Figure 5. Service quality

Source: Wilma Lyon, (2008).

It suggests that designing service excellence, responsive to consumers and others as the principles of service quality are needed before designing strategy, systems and HRM planning. The results of consumer and staff satisfaction will be achieved with the implementation of strategic planning system planning and HRM planning.

The USA, the UK, Ireland, Malaysia, Japan and Bangladesh have successfully implemented different approaches of this model as shown in chapter 3, 4 and 5.

Gaster (1995) model for service quality:

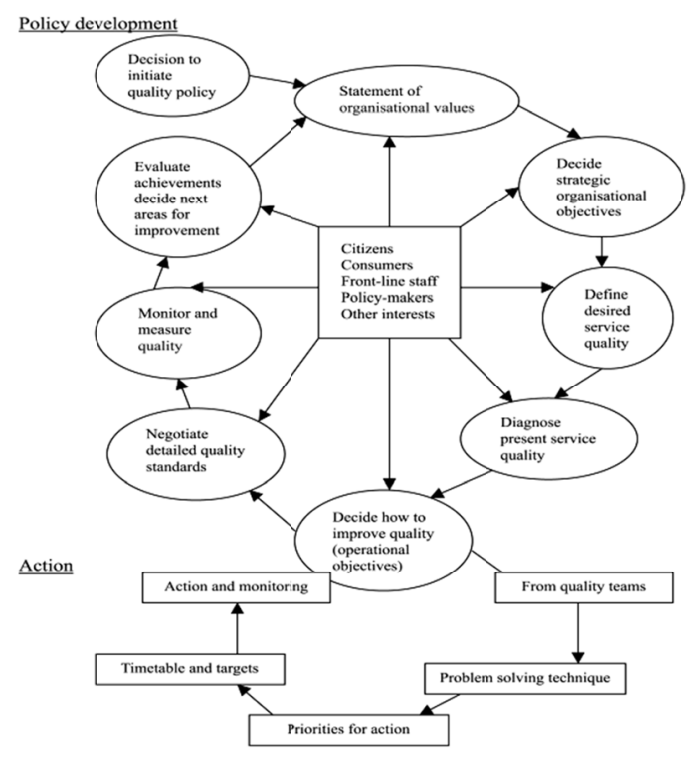

Figure 6. Quality improvement model

Source: Gaster (1995 p. 6).

Gaster (1995) model for service quality, as shown in figure 8, has an important implication in improving public service quality. Humphreys, P.C and others (2000) explained the model as a process of improving customer service quality.

Australia has launched 'Centerlink' (see in chapter 4) in government services in 1997 and Yamaguchi City Hall, Japan has launched 'reform of the management board for the autonomous community building through collaboration' (see in chapter 5) with the aim of increasing stakeholder's involvement in the service quality process throughout the formulation, implementation and evaluation stages. There cannot be one formula for quality-each organization has to develop its own approach (Lawton \& Rose, 1994). The foregoing review 
indicates a range of different techniques and models for ensuring the effectiveness of public service delivery. Therefore, there is a need for developing comprehensive model with the combination of different approaches to achieve the research goal.

\section{Field Administration and Public Service Delivery System in Bangladesh}

\subsection{Field Administration of Bangladesh}

In France, since the time of Napoleon, field organization has been a tool for representing the central authority in the sub-national area (Hoque, 1982). Field administration of Britain has also been developed to decentralize administrative capacity of the central government. British India field administration was developed like France system. After independence in 1947, India and Pakistan inherited the British India pattern of field administration (Obaidullah, 1999). After independence in 1971, Bangladesh also inherited the same philosophy and pattern of field administration i.e. decentralization of administrative unit to the local level and still now it continues with some modification.

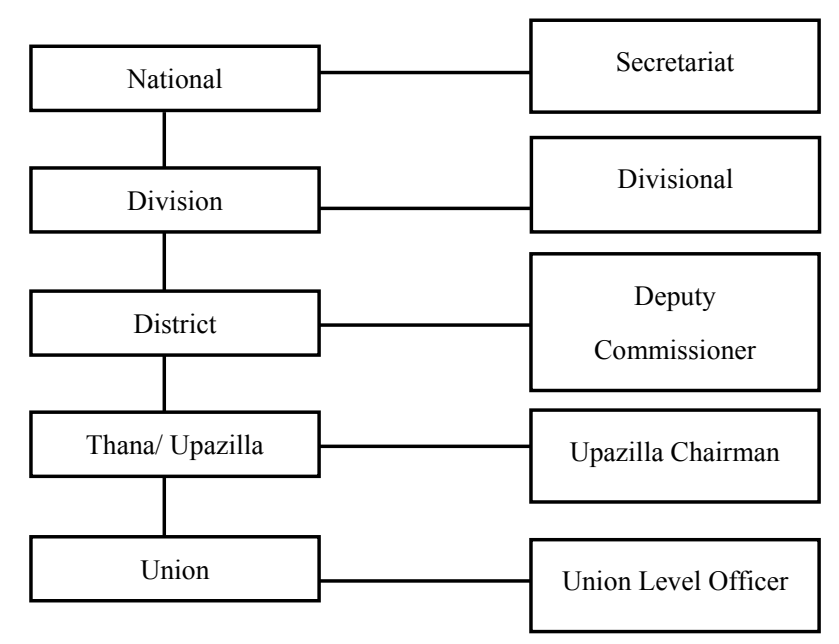

Figure 7. Present set up of field administration Bangladesh

Source: A.T. M. Obaidulla (1999).

The government of Bangladesh has a two-tier administrative system. The upper tier is the central secretariat at the national level consisting of the ministries and divisions to provide policies and to perform clearinghouse functions. The other tier consists of 'line' departments/directorates attached to the ministries and divisions that are mainly responsible for general administration, service delivery to citizens and implementation of various government development programs at the sub-national level (Ahmed, 2002). Field level administration in Bangladesh comprises divisional administration (7), district administration (64), upazilla administration (487) and union administration (4498). Present set up of field administration in Bangladesh is shown in figure 9.

\subsection{Deputy Commissioner: The Pivot of the District Administration for His Services and Functionaries}

The Administrative unit that figures prominent in this country is called district, which is headed by an accomplished professional having long and laudable experience called Deputy Commissioner/ District Magistrate who is expected to be highly talented and gifted with good leadership quality. S/he represents government at the field level, conduct all polls and act as Collector, development co-coordinator, disaster manager, and guardian of criminal administration at the lower level. S/he is the chief protocol officer representing government ceremonies on behalf of the national government. To be brief there are little or no activity in the district, which is unrelated to him/her by some way or other (website of MoPA, Bd). According to the Government order of Cabinet Division, order number CD/DA-1/4(2)/83 (PT. 11)-465 DT.10-11-83, Deputy Commissioner performs 153 categories of functions (Cabinet website, Bd). Therefore, Deputy Commissioner is considered to be the pivot of the district administration. According to Dr. Syed Nasar Ahmed Rumy (2006), Office of the Deputy Commissioner is like the nuclear in the district cell.' In a word DC is the spoke man, eye, ear and nose of the government in the District level.

It is assumed that public service in Bangladesh is not functional. Although government has taken various initiatives to improve the performance of the government offices, unfortunately the level of customer 
satisfactions is very poor. Thus, a strategic and tactical system level framework and model of effective public service delivery can be effective in improving the performance of the government offices and achieving the status of customer satisfaction. As a pivot of the district administration a research can be conducted on the Deputy Commissioner office to introduce such a model of effective public service delivery and to experiment it to other government offices Bangladesh as well to boast up good governance.

\subsection{Policies and Practices Adopted in DC Offices to Ensure Effective Public Service Delivery}

Since independence, DC office took following reform initiatives to ensure timely and corruption free public service as well as to ensure effective public service delivery:

1) Introduction of Citizen Charter: Charter approach can be an important tool in ensuring public service delivery, the evidence of which has been reviewed in Chapter 2. Different government offices including DC office introduced Citizen Charter by the Government circular ordered on 21 May 2007 (Citizen's Charter: a manual, 2010).

2) Enactment of Right to Information Act, 2009: Research evidence provided in Chapter 2 indicates information sharing as the means of ensuring citizen rights. Bangladesh adopted the Right to Information Act 2009 at the first session of the 9th Parliament on May 29 (Citizen's Charter: a manual, 2010).

3) E- Governance: Literature review indicates that there is a need for cross-service communication and information flows as well as e-governance in ensuring effective public service delivery. The vision of Digital Bangladesh by 2021 (see Karim \& Md. Abdul, 2010) posses to mainstream of ICTs in all spheres of government. The District web-portal that was launched in 2009 by DC office.

4) Office inspection: Literature review proves that monitoring and reviewing is very necessary to control service process as well as ensuring public service delivery. In DC office, office visit or inspection has been used as a means of monitoring and reviewing the activities of the employee.

5) District monthly meetings: District monthly meeting, district revenue meeting, district laws and meeting, district local government meeting and district commodity price control task force meeting, are the best example, is another way of monitoring the performance of the office as well as ensuring the accountability to the district administration.

6) Performance appraisal in the civil service: Performance appraisal or evaluation of employees, the evidence of which has been provided in literature review, is also used in DC office. In DC office, Annual Confidential Report (ACR) written by immediate superior of the office and counter signed by the head of the office is used as a means of evaluating the performance and getting promotion.

7) Discipline and appeal in the civil service: Evidence of literature review provided in chapter 2 indicates that cultural change by changing basic norms, attitude, behavior and belief of employees can be an effective tool for maintaining employees discipline and improving quality public service. The important rules and regulation related to the discipline and Appeal for the Civil Servant includes, the Government servants (Conduct) rules 1976; the Government servants (Discipline and conduct) rules 1976; the Government servants (Special Provisions) Ordinance 1979; the Public employees Discipline (Punctual attendance) ordinance 1982; the Civil service (Prevention of Corruption) Rules 1947.

8) Recent reform initiatives taken by the government: Recently, Bangladesh government has established Good Governance Unit (GGU) in the Prime Minister office to work on ensuring the good governance in every public office. The government has also introduced award system for excellent performance at the national level. The government is going to establish e-service centre in every DC office to receive online petition and online service delivery (The daily Prothom Alo Newspaper, 2011). Union Information service Unit (UISC) has been established in every Union Parishod (lower level of local government) of Bangladesh where people can collect all sorts of information.

\subsection{Problems of the Public Service Delivery in the Deputy Commissioner Office}

Bangladesh has been inherited the British administrative system that was established by British Colonial Authority in the period of 1757-1947 to maintain law and order, collect revenue and dispense justice. The Administration was fundamentally bureaucratic in character and relatively stable; changes tended to be in the nomenclatures of positions in the structure rather than changes in responsibility (Azizuddin Mohammad, 2008). With the inherited British structure and functional process, the DC office faces with the following problems in delivering public services to citizens. 
1) The Inefficiency of the receipt and dispatch section: All the correspondence between DC office and service seekers are done through the receipt and dispatched section. Due to the inefficiency of this section people suffer a lot in getting their desired services (see Siddiki \& Kamal, 2006).

2) Problem of workstation: Bangladesh bears a colonial legacy in its entire public administration system (Jahan \& Ferdous, 2006). The DC offices are inherited with closed workstation system as well as individual room for individual officers. It hinders conductive working environment and cross-service communication and information flows and motivates corruptions.

3) Problem in use of machine in DC office: The use of computer, photocopier machine, fax, internet, telephone has enhanced the efficiency of DC office in serving the customer (Siddiki, Dr. Kamal, 2006). However, the work load in DC office is such heavy that in every section a large number of Dealing Assistants (DA) wait to compose letter or file note in a single computer. On the other hand, lack of proper training in operating and maintaining the machineries makes barriers in efficient public service delivery.

4) Problem of existing performance appraisal system: Annual Confidential Report (ACR) is used in DC office as a means of measuring the employee performance. But it is a matter of criticism due to its unethical practice. It appears that the performance appraisal process is a one-way traffic (Alam, M. S., 1996 \& 1997). It is not written and are found to be arbitrary and influenced by personal-pull or tadbir or other connections or malpractices (see more Monem \& Islam, 1997, p. 53). Moreover currently introduced PMS is a quantitative rather than qualitative.

5) Corruption: Another problem of the district administration is corruption. Corruption in Bangladesh emanates from both politics and administration. In most of the cases it takes places in the form of bribery. Besides, misuse of power, nepotism, fraud and patron-client relationships also gives rise to corruption (TI-Bangladesh Documents Report, 1999). This year Bangladesh ranked $13^{\text {th }}$ position in the corruption perception index in the public sector, holding 2.7 points in the world (Corruption Index, TI, Report, 2011).

6) Centralized administration: Field administration in Bangladesh is strictly controlled by the central government and is responsible for excessive bureaucracy, delay in decision making and lack of benefit for people (see more Documents Report, TI-Bangladesh, 1999).

7) Luna M. David (2002, p. 2) states that "dishonest, corrupt and unethical behavior among public official undermines the trust and confidence of the people that government can do good work and advance the public interest and ultimately weakens the good governance initiatives in the country". With highly centralized bureaucratic atmosphere public servants don't take any initiative to practice ethical conduct and uphold values in the interest of good governance (Majumdar \& Md. Nazrul Amin, 2005). The rules and regulations regarding discipline of the government employees are enacted by the central government. Field administration cannot formulate, even update them, if necessary, like developed countries. Most of them are not adequate enough to deal with acute inefficiency; indiscipline and danger of corruption in the civil service (see Subramanian, 1990). Moreover, little attempts have been made to consolidate them into one single meaningful body of rules (see Azizuddin, 2008). Another problem related to the rules and regulation is its implementation. Till now government fails to formulate Civil Service Act.

8) Problem of the implementation of e-Governance: According to the World E-Governance readiness index 2001, Bangladesh holds $159^{\text {th }}$ position $(0.165)$ among the 173 countries. Internet accessibility is 1.532 out of 1000 persons with 0.003 internet index (United National World Public sector Report 2003, p. 230). With this few introduction of ICT, Bangladesh cannot ensure effective service delivery just now. On the other hand, lack of uninterrupted power supply in Bangladesh also create problem in ensuring effective public service delivery through internet.

9) Lack of Motivation: Promotion and posting of the government employees in Bangladesh is not merit based. On the other hand, salary system is not performance based. Although government has introduced reward system for excellent performance, but it is very limited and centrally introduced. There is no any rewarding system in the field administration to recognize excellence. It is believed that, lack of motivation is responsible for low performance of government employees.

As the pivot and the coordinator of the district administration dealing with a lot of functions, citizens have the trust on DC office, in getting timely and corruption free quality public services. It needs to introduce new approaches and tools as in the case of developed countries and utilize the concept of NPM and other research evidence in this field to make customer-oriented and pro-people district administration. 


\section{International Context to Public Service Delivery}

A review of the international context highlights a range of different mechanisms taken by different countries that have been succeeded in achieving effective public services delivery. Implication of content and process issues of ensuring effective public service delivery as well as NPM, as described in chapter 2 , has been briefly explored in the review of the USA, the UK, Australia, Ireland and Malaysia example.

\subsection{The United States of America (USA)}

Service delivery reform in public sectors of the USA is a matter of continuous process and mostly influenced by the changing management thought with the notable contribution of Osbonre and Gaebler (1992). Major reform initiatives in USA are as followed:

- The Major reform initiatives taken by the Federal Government of USA in 1993-94 were identifying the customers to be served; surveying their level of satisfaction; setting post service standards and measuring results against them; setting Benchmark customer service performance; improving front-line services; making customers choices in both the sources of service and the means of delivery; making information available; improving means to address customer complaints (Executive order 12862, 1993).

- In 1995, the head of the Executive departments and agencies were requested to survey the need of the employees and to take action to motivate and recognize them (President Memorandum, 1995). Federal government agencies have successfully introduced performance-based pay system in place of tenure-based pay systems (U.S. Merit Systems Protection Board, 2006).

- In 1998, each agency was asked to talk with citizens to discover what is most important to its customers and what the federal government can do to meet their expectations and to use this information to improve service standard (President Memorandum, USA, 1998).

- In 2011, Government managers were asked to learn the private sector and apply the best practices to deliver services better, faster, and at lower cost (Executive order 13571, 2011).

- Each agency was asked to develop a Customer Service Plan to address how the agency will provide services in the following areas (Executive Order 13571, 2011):

Establishing signature initiative using technology to improve the customer experience; develop customer feedback mechanism; develop customer service standards and expectations; Improving the customer experience by adopting proven customer service best practices and coordinating across service channels (such as online, phone, in-person, and mail services); streamlining agency processes to reduce costs and accelerate delivery.

- In every executive department and agency in USA a post of Chief Performance Officer responsible for ensuring the service delivery was created to develop guidance for implementing the activities of the customer service plan.

\subsection{The United Kingdom (UK)}

In the UK, increasing the pressure on public spending led to go for budget cut for less important sectors and need to focus on improved efficiency so that the same and better outcomes can be secured with lower inputs

(OECD, 2010). For this purposes, the mater of quality public services delivery was given importance. Some of the important reforms to ensure public service delivery in the UK are given below:

- Privatization in 1980 was the first initiative in the UK for improving the public service delivery by reducing the role of the state as a direct service provider in major areas, such as gas, water and electricity (Humphreys, 2000).

- In 1991, the UK government set out their proposals for a Citizen Charter in a white paper (Humphreys, 1998). Focusing on qualities, choice, standard and value, the charter was introduced with a set of principles in public (Humphreys, 2000). Performance of raising standard and responsiveness are evaluated and reported to the Parliament. Citizen Charter complaints task force was established in 1993 to handle the public service complaints.

- UK Commission for employment and skills launched IIP (The Investor in People) as a business improvement tool to improve organizational performance through the effective management and development of their people. A total of 2000 UK firms received the IIP standard by 1995 (Humphreys, 2000).

- PPP (Public Private Partnership) is another reform initiative to improve the quality of public service delivery in the UK (see more OECD, 2010). 
- The UK government is very much committed to establish a 'Big Society' to give more power and opportunity into citizens, communities and local government hands needed to come together, solving their and community problems.

- Many local council and their public service partners are being integrating their services to cut duplication and waste of expenditure and to provide more joined-up services for service users in UK (OECD, 2010). Local Integrated Services (LIS) is such a type of pilot project in the UK.

- With a view to provide better, more efficient services and support public service transformation, the UK government launched online delivery of public services recommended by the Cabinet Office Efficiency and Reform Group (Osborne \& Gaebler, 1992)

- In the UK during the 1980 s, many government departments were fundamentally restructured to create separate executive agencies directly responsible for service delivery to make separation between policy making and service delivery (OECD, 2010).

- Transparency is the key to the efficiency drive in the UK. A public sector Transparency Board monitored by the Cabinet office was established to oversee the implementation of the transparency commitments of the UK government. The Board is responsible for setting open data standards across the public sector and developing the legal Right to Data.

\subsection{Australia}

Public sector reforms in Australia have focused on achieving a more efficient, effective and responsive public service, rather than being a re-examination of the fundamental role of government (McNamara, 1995). Some of reform initiatives are described below:

In 1997, Australian government launched 'Centrelink (one-stop-shop) (Note 1) to improve customer service, enable quicker decision making and enhance value for money through service linkages. The establishment of Centrelink clearly separated policy from service delivery. Service quality tools under Centrelink as described by Peter C. Humphreys (2000) are: creation of 'Centrelink Charter' (commitment of the organizations); value Creation workshop between staff and customers (discover customer expectations); evaluation of performance using 'balanced scorecard approach'; established a comprehensive customer feedback and complaints mechanism' conducting staff training to connect staff to the strategic development of customer service culture. Australia is one of the best examples of developing an internationally distinguished ethical public service that considerably towards good governance (Majumdar, \& Md. Nazrul Amin, 2005). According to Majumder (2005), 'APS is firmly based on ethical performance. Definite value and a code of conduct for APS employees ensure better services for Australia citizens'. Most of the rules have been combined under the PSA, 1999 in Australia. APSC always works for the promotion of ethics in the civil service. In May 2009 APSC Commission introduced an Ethics Advisory Service (OECD, 2010).

\subsection{Ireland}

Public Service delivery reform in Ireland actually started from 1980s. Major initiatives are described below:

- Irish government launched QCSI (Quality customer Service Initiative) (Note 2) in May 1997 to ensure standard of service quality by the public organization. The principles of QCSI as summarized by Humphreys (1998) are: service specification; service standard; way of service communication; customer consultation; monitoring and review of service standard achievement.

- With the recommendation of 'Delivering Better Government (1996)' report each Department/Office of Ireland had to publish a two-year Customer Service Action Plan in 1997/98 focusing on the key areas of service improvement. The major areas of achieving improved standards of service delivery in Ireland as stated by Humphreys (2000) are; Information, timeliness and Courtesy, consultation, choice, better Co-ordination, complaints, redress and access.

- Ireland introduced Charter of Right under the public management reform project in each government office in 1989.

- Ireland government enacted Public Service management Act, 1997 requiring every department/office publish their statement strategy of achieving service standard as specified by the government and submit to the House of the Oireachtas for monitoring its advancement by an all party committee (Humphreys, 1998).

- With a view to provide the institutional framework for the improvement of the quality of services, the Ombudsman Act was enacted in 1980 to handle public complaints ((Humphreys, 1998). Moreover, the 
enactment of Freedom of Information Act, 1997 increased the quality public service delivery a lot and reduced customer complaints to Ombudsman in Ireland.

\subsection{Malaysia}

Malaysia worked a lot in its reform initiatives in public services the Five years plan, Eight Malaysia Plan (2001-2005) and Ninth Malaysia Plan (2006-2010). Major Reform initiatives taken by Malaysia government are given below:

- Establishment of Development Administrative Unit (DAU) in PM office, National Training Institute (1972), Public Service Department (PSD) and Malaysian Administrative Modernization and Management Planning Unit (1977); reorganization of establishment office (1970); modification of current recruitment, promotion, discipline and personnel management evaluation policies and practices are some example of restructuring Malaysia government system.

- Under the privatization policy 1980, more than 150 enterprise were privatized which reduced public service by 65,000 people and financial burden by M 4.2 million per year in Malaysia.

- With a view to make more customer-oriented and business friendly working environment, different departments and agencies in Malaysia introduced one-stop services facilitated by Multi-service, emergency service and special service counters. To update the front-line services government introduced the extended service hours, electronic queue management system, one-stop bill payment counters, GIRO system, on-line computer system, general information telephone system, customer feedback system, floor managerial system, Customer Service Office (CSO), training and guidebook system.

- With a view to increase the service efficiency, government issued different circulars and letters connected with office procedures, corresponding desk file, meeting management, and open office system.

- In 1993, the government introduced Client's Charter to every agency to ensure delivery of goods and services to its customers in a predetermined standard.

- In Malaysia, many agencies modified their service procedures by reducing the number of copies and information needed to submitted for getting different services such as application for licenses (see more Karim, 1995).

- With a view to reduce bureaucratic red tape Malaysia government established ministerial task force in 2003. The task forces were assigned to improve the existing work systems and procedures to ensure efficient service delivery and prevent abuse and corrupt practices (Ninth Malaysia Plan, 2006-2010).

- The Malaysia government continued to promote and recognize organizations for their excellence through introducing Prime Minister's quality award program, premier ICT award, innovation award, quality control circle award, premier local authority award and the premier land and district administration award.

- Malaysia Government introduced MS ISO 9000: 1994 standard to recognize organizational excellence in providing customer-oriented services. Those organizations which achieve the ISO 9000:1994 standard in providing customer oriented services could get MS ISO 9000: 1994 certificates with rewards (Ninth Malaysia Plan, 2006-2010).

- Among the improvement in office automation and information systems in public offices of Malaysia, the electronic data interchange system, Public Service Network (PSN) and the Civil Service Link (CSL), and customer database are important to mention.

- The government has introduced performance measurement systems at the individual and organizational level in 1993 (Karim \& Mohammad Rashid Bin Abdul, 1995). Efforts to enhance services were further strengthened with the introduction of performance measurement and KPIs to support a higher level of service by agencies (Ninth Malaysia Plan, 2006-2010).

- The public service of Malaysia is guided the TQM maintaining customer interest with zero defects, high performance and customer demands fulfillment and process work (Karim \& Mohammad Rashid Bin Abdul, 1995). With a view to ensure TQM, government introduced QCC program in 1983 and issued different circulars.

\section{A Case Study: Yamaguchi City Hall, Japan}

The purpose of the case study analysis of Yamaguchi City Hall was to introduce practical example of introducing different approaches and tools and their effectiveness in ensuring public service delivery in the field administration of Japan for the development of benchmark framework and subsequent comparative study. Direct interview was conducted with the responsible officers of the International Affair Division of the Yamaguchi City 
Hall.

Yamaguchi City Hall is a local level administrative as well as the policy implementing unit of the Yamaguchi City that ensures citizen welfare and facilities and is accountable to the Yamaguchi City Council. It stated its reform initiatives since 1995. Before the reform initiatives, Yamaguchi City Hall had its long time experiences of facing the challenges of growing number of aged population, large volume of public expenditure and Local Allocation Tax Grant (LATG), stagnant economic growth and a good number of non-served and dissatisfied people located at the remote area. On the other hand, the growing importance on tourism, health and medical, social welfare, social education, agriculture and public dealings with the Yamaguchi City made Yamaguchi City Hall to go for reform initiatives. To face with those challenges Yamaguchi City Hall took following public services reformative initiatives:

Yamaguchi City Hall has successfully developed the autonomous community with the involvement of citizens and voluntary groups. 'Urban development through Cooperation' project was taken to work together with the citizen group in 2010 (Yamaguchi City Hall website). With a view to improve delivery of services, Yamaguchi City Hall delegates some responsibilities to different private sectors related to tourism, social welfare, culture and sports, chamber of commerce and industry, medical, agriculture, firming and fishery. Electronic networking system, digital file management, citizen data base, digital land management, public service delivery through internet, public complaints and resolution etc are important achievement of installing e-governance there. To make the city hall Open and transparent 'Information disclosure ordinance 2000' has been enacted. Moreover, the publication of public paper (newspaper) in every two weeks and positive role of the media, citizens, volunteer groups and pressure group make the City Hall more transparent in its daily works. When formulating the policy etc. citizens are given opportunity to express their valuable opinions. Policy making and implementation has been strictly followed by law and practice. To reduce corruption all office files are cross checked by different level office staffs and those who are involved in any bribery or corruption, are condemned to 5 years imprisonment (Criminal Code, Article 197, Yamaguchi, Japan). Work station system of Yamaguchi City Hall is technically well equipped, open and citizen friendly. All officers of the respective divisions work in a group in an open and friendly environment room which minimizes time, cost and corruption. With a view to make more customer-oriented and business friendly environment, Yamaguchi City Hall has introduced counter service system. There is also a special counter for old and disabled citizens as well as a special counter to handle the complaints from the citizens. Yamaguchi City Hall offers citizens one stop service counter where varieties of services are delivered. Branches of the different banks and offices of the utility services are also under the same building to expedite the delivery of services to citizens. Yamaguchi City Hall enjoys flexibility and independency in elaborating budget, imposing local tax, collecting revenue, spending money and making rules and regulations for employees and office management for the welfare of the citizens. Yamaguchi City Hall has successfully established a basic policy to conduct a personnel qualitative evaluation system for staff. According to the article 40 of the 'Public Servant Law', personnel appraisal system in Yamaguchi City Hall is conducted under two methods on a regular basis: Personnel evaluation through competency and Personnel evaluation through Performance evaluations (Website of Secretariat of National Personnel Authority, Japan).

The forgoing case study suggests that Yamaguchi City Hall has been successful in applying different approaches, techniques and models of scholars, practitioners and researchers as well as the concept of NPM as described in the literature review. As a result, it enhanced and in many cases re-modeled public service delivery and achieved the desired level of customer satisfaction. A good number of facilitating mechanisms enables the City Hall to this transformation. Firstly, delegation of some service responsibility to private sectors; engagement of citizens and volunteer groups made possible to patronize the private sectors and social organizations and to improve the service quality. Secondly, extensive use of IT made possible the structural change in the service delivery process of the Yamaguchi City Hall. Thirdly, proper implementation of Information Disclosure Ordinance (2009); publication of public paper weekly; giving importance on citizens in formulating any laws or policy; taking severe action against corruption; maintaining accountability to City Council and role of the media and pressure group made Yamaguchi City Hall to be open and transparent. Fourthly, open work station system, facilities of counter services and one-stop services made the Yamaguchi City Hall to have conductive working environment in ensuring effective public service delivery. Fifthly, proper HRM helps the employees of the Yamaguchi City Hall to be more responsible, efficient and pro-people administration. Finally, flexibility, independency, decentralization of decision making, separation of policy and implementation made the Yamaguchi City Hall to take timely decisions and implementation for the improvement of service quality.

According to the authority of the International Affairs Division, Yamaguchi City Hall has achieved a desired level of trust from the citizen in delivering the services with satisfaction. Therefore, the case study analysis of the 
success story of Yamaguchi City Hall can serve as the learning example to develop a benchmark framework of effective public service delivery. Then the elaborated benchmark framework can be applied Bangladesh experiences to ensure effective public service delivery in the field administration of Bangladesh.

\section{Results and Discussion}

Having developed a conceptual knowledge of effective public service delivery in chapter 2; reviewing the Bangladesh and international experiences of public service delivery in chapter 3 and 4; analyzing the case study in chapter 5; it is necessary to develop a benchmark framework to explore a strategic and tactical systems level framework and model of effective public service delivery. As a result of analysis, this chapter has come up with some recommendations for making the field administration of Bangladesh more effective and efficient in delivering the public service to citizens.

\subsection{Benchmark Framework and Comparative Analysis}

Benchmark framework of effective public service delivery, as developed and shown in figure 13, is a set of guiding principles that will help to assess the strengths and weaknesses of the current practices of public service delivery and to thus to find the way to improve. The benchmark framework comprises nine core principles of effective public service delivery. Those are as follows:

\section{1) Focusing on the organization's purpose and outcomes for citizens and service users}

It is argued that ensuring effective public service delivery will not be effective if it is not linked with strategic objectives and value of the organization. More evidence has been provided in Gaster (1995) model (see in chapter 2). In Bangladesh, although DC office has a long historical background of serving the citizens, now it is considered as an institution to fulfill political will. Moreover, there is no any clear statements on organization's purposes and outcome for citizens and service users as well as linkage with service delivery mechanism there.

\section{2) Setting clearly defined functions, roles and responsibilities}

It is evident from the literature review that effective public service delivery requires setting a clearly defined functions and services to achieve organizational goals and being clear about roles and responsibilities. In the case of Bangladesh, functions of the Deputy Commissioner are clearly defined in the name of Charter of Duties by the government order of cabinet division number CD/DA-1/4(2)/83 (PT.11)-465 DT.10-11-83.

\section{3) Setting public service value/standard}

Research evidence provided in literature review suggests that these service standards will help developing nationwide consistent level of public service and improving public service efficiency. In Bangladesh, unfortunately there is no evidence in the DC office to develop the standard of public services delivered to citizens. By introducing charter of duties, government tried to promise timely and corruption less public service. However, it is not comprehensive and effective as in the case of the USA and the UK.

\section{4) Preparing Customer Service Action Plan (CSAP) to achieve the service standard}

It is evident from both the review of literature and analysis of international experiences that each public office should prepare and publish a Customer Service Action Plan (CSAP) to achieve and improve service standard progressively. In Bangladesh, there is a national level three years action plan for poverty reduction named PRSP. However, there is no any planning initiative for customer service in the field administration of Bangladesh.

\section{5) Developing the capacity and capability of people, designing the service strategy and contracting}

This principle is fundamental to effective public service delivery. The process can be designed in the following three areas: people, strategy and contracting. 


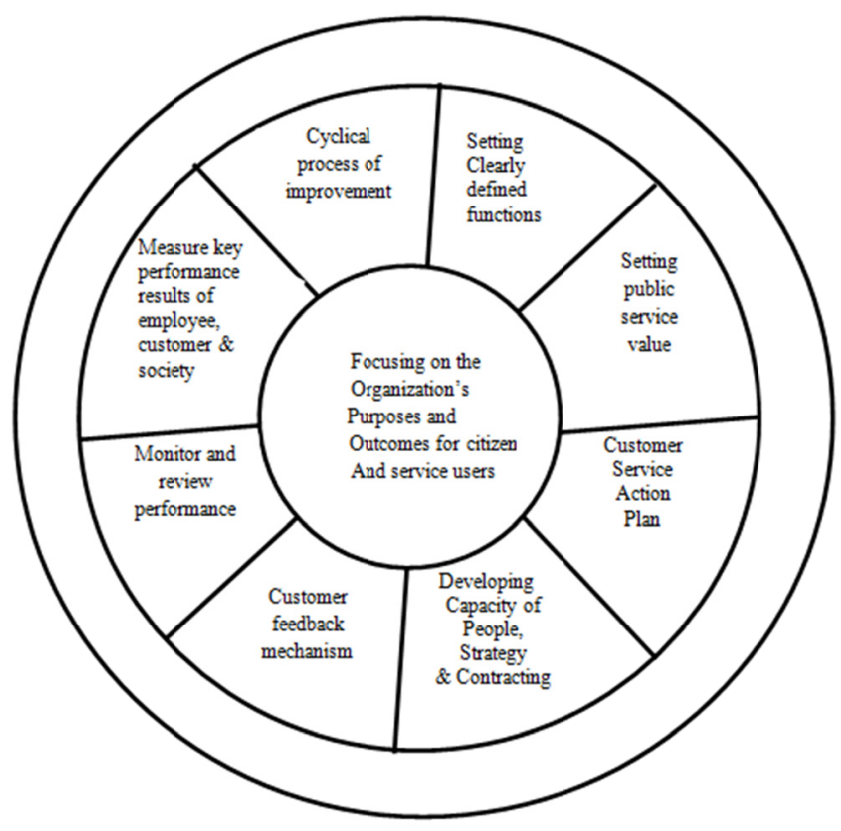

Figure 13. Benchmark framework of effective public service delivery

\section{People}

It is recognized that employees play a central role in achieving excellent customer services. Proactive leadership, training of the staffs, employee's motivation and recognition, conductive working environment, moral and ethical practices and personnel capacity management plan and appraisal system will be the benchmark tools for developing capacity and capability of people in ensuring the public service delivery. In Bangladesh, we have much scope to develop the capacity and capability of people.

\section{Strategy}

Research evidence provided in literature review, international experiences and case study analysis indicate that a good number of tools and approaches may be the benchmark are necessary for benchmark in designing strategies for ensuring public service delivery such as; TQM, decentralization/separation of policy and service delivery, one-stop shop, e-governance, information sharing, counter service approach, flexibility in decision making, re-engineering, charter approach, separate administrative unit for good governance, office management manual, citizen database, decentralization of decision making and sources and means of service delivery. In Bangladesh, except only a few initiatives such as launching e-governance, enacting Right to Information Act 2009, introducing Citizen Charter and updating secretariat instruction were taken; no other tools have been introduced to ensure the quality public service delivery.

\section{Contracting, Partnership and engagement}

Research evidence provided in literature review, international and case study analysis indicates that tools of contracting, partnership and engagement such privatization, PPP, engaging citizens and voluntary group, coordination with local government and benchmarking the best practice of customer service from the private sectors can be the benchmark for effective public service delivery. In Bangladesh, it is not evident that any significant step was taken to delegate the responsibility of public service to private sector or engagement of citizens or voluntary groups.

1) Developing a customer feedback mechanism, handling customer complaints and improving customer experience;

Evidence from literature review, international experiences suggests that customer feedback and survey, customer panels, complaints mechanism can be practiced to improve public service delivery. Customer satisfaction feedback and complaints mechanism (Malaysia, USA, Australia example); citizen charter complaints task force (UK example) Ombudsman Act (Ireland example) for example can be the best practiced for this purposes. Despite such efforts taken by the other government, no instance has been found in Bangladesh regarding 
developing the customer feedback mechanism and improving customer experience.

\section{2) Developing a mechanism to monitor and review the performance;}

There should be a strong monitoring and reviewing system in public organization to ensure the public service delivery emphasized by Gaster (1995) model. Appointment of Chief Performance Officer (USA example); conducting independent review by Independent Commission (Ireland example), setting individual and group quantifiable target and monitor through frequent inspection and meeting (Malaysia example); establishment of Citizen Charter task force for examples, may be the benchmark for these purposes. In Bangladesh, office inspection and district monthly meeting are two important tools introduced by DC office to monitor and review the performance as well as ensuring transparency and accountability (see details in Chapter 3). So far, there is no any innovation in the inspection and monthly meeting.

\section{3) Measuring key performance result of people, customer and society;}

Key performance result will be achieved though the evaluation of people, customer and society results as stated in EFQM of literature review. Quantitative and qualitative competency and performance evaluation of the employee (Japan) by Introducing KPI (Malaysia) or Balanced Score card approach (Australia) may serve this purpose. Customer results can be measured conducting customer satisfaction survey. Society results can be measured by evaluating outcomes on society. Although in Bangladesh ACR is used as a means of evaluating the performance of the employees, no significant step has been taken to measure the employee's competencies as well as key performance results of customer and society.

\section{4) A cyclical process of continuous improvement;}

Ensuring effective public service delivery is a continuous process like development. It is necessary to evaluate the achievement by comparing the key performance results with the service standards. If there remains any lacking in operation then it can be suggested for taking necessary action for improvement.

In Bangladesh, there is no significant evidence of taking initiatives to identify gap between citizens expected services and perceived services to improve the public service delivery. Moreover, no suggestions are offered from citizens to update the service delivery system in the field administration of Bangladesh.

\subsection{Strategic and Tactical Systems Level Framework and Model of Effective Public Service Delivery}

With the comparison of benchmark framework and Bangladesh experience a strategic and tactical systems level framework and model of public service delivery, as shown in figure 14, is suggested to be introduced in the field administration in Bangladesh. The model assumes that service measure such as key performance result is achieved through a number of stages starting with setting organizational values, goals and outcomes for citizens and service users. A clearly defined functions, roles and responsibility should be defined aiming to achieve the organizational goals. What standard a public organization should maintain in operating public services should be set by individual government office. Identifying the gap between customers expected service and perceived service through a series of surveys, customer panels, complaint procedures and MIS can help in developing the values and standard of services.

Next stage comes up with the preparation of annual CSAP. As per the plan a service design mechanism should be developed aiming to increase the capacity and capability of people, strategy and contracting. Tools used in the process of service design should be controlled by a strong customer feedback mechanism and effective monitoring system. Customer feedback mechanism will lead to the improvement of the customer experience and handling the customer complaints.

Then a key performance results is achieved by measuring the people results, customer results, and society results. Evaluation of the achievement, by comparing the key performance results and service standards, is necessary to identify the lacking area in the process.

Customer experiences and suggestions from evaluation of achievement will be used in setting service standard and preparing CSAP to introduce necessary correction in service design in a cyclical way for improvement. 


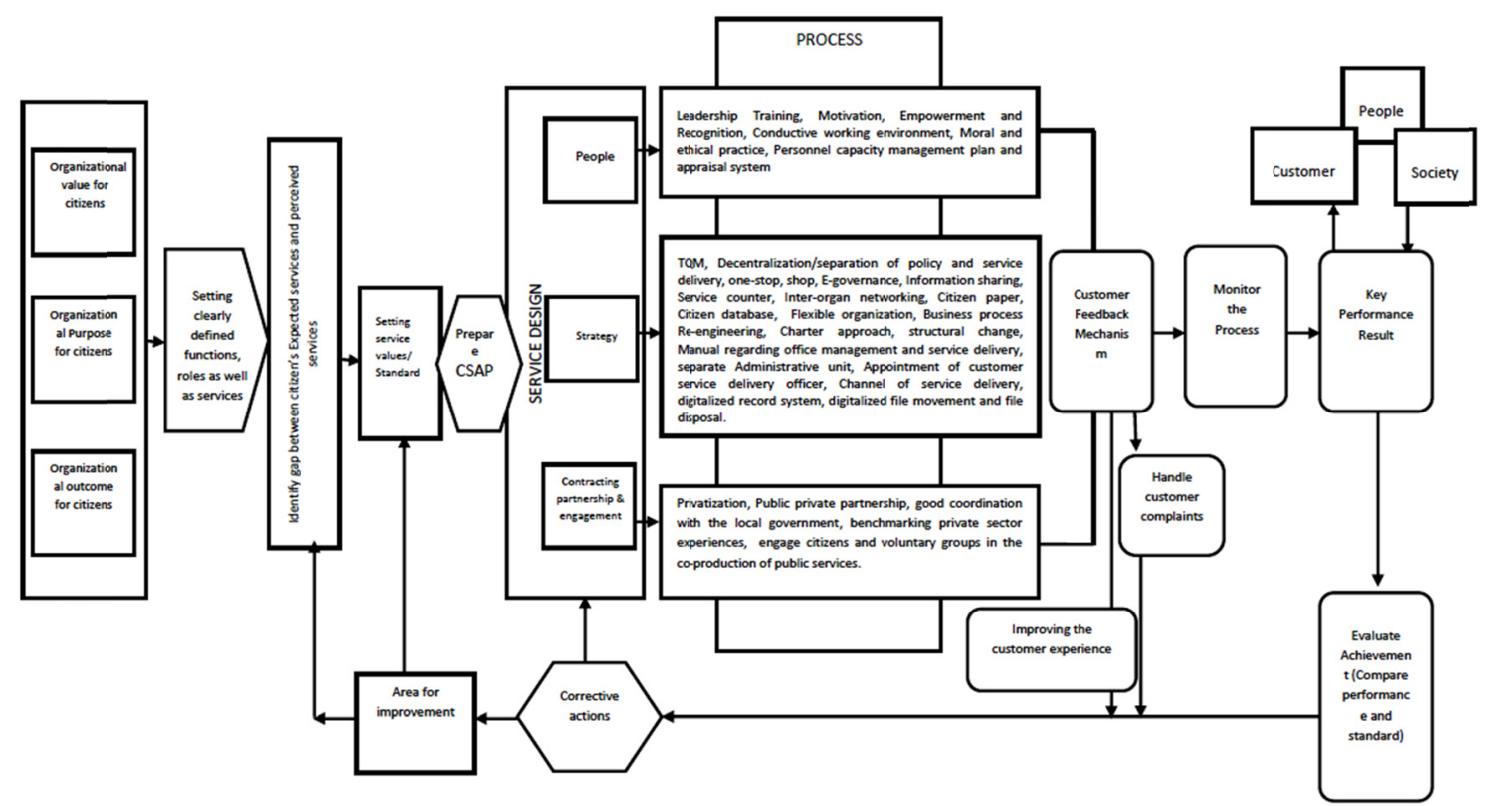

Figure 14. Strategic and tactical systems level framework and model of effective public service delivery

\subsection{Recommendations}

The framework and model, as shown in figure 14, has an important implication in achieving the research goal. Comparing the current mechanism used in DC office with the strategic and tactical systems level framework and model of effective public service delivery, one can identify the following implications for future practices to ensure effective public service delivery in the field administration of Bangladesh.

1) There should be a statement of goal for citizens and service users in DC office to make a linkage with service delivery plan and setting the service standard towards functionaries. A customer service action plan should be published to guide and improve service delivery process and to maintain the stated service standard.

2) The government should launch the following approaches along with the tools to existing systems in order to ensure the smooth and effective public service delivery.

- There should be a continuous and formal training program for office staff especially in the field of office management, file management, public relation, computer literacy, attitude, behaviour, moral and ethics.

- The government should introduce performance based pay system to motivate the government employees. To recognize excellence in performance, different types of rewards system should be introduced in the field administration. There could be an introduction of ISO9000 certificate to different departments of field administration to achieve internationally recognized standard of performance.

- Open work station system should be introduced in DC office to create the conductive working environment.

- The government should develop definite value and code of conduct for the government employees and combine all rules in one law. There should be a periodic training program in the DC office for ethical learning. Moreover, there should be a separate body responsible for the promotion as well as planning, monitoring, advising ethical standard among the employees. The government should enact Ombudsman act (see Ireland example) or establish task force (see UK example) to handle public complaints against any government employees.

- Personnel appraisal system should be updated by introducing both employee competency evaluation and performance evaluation (or PMS) and should be used as the basis for promotion, demotion, pay raises, bonuses and dismissals.

- The selection authority should justify the leadership quality of DC before appointing him as DC.

- TQM approach should be introduced in DC office to facilitate file movement, reduce time of file disposal, improve standard of service and improving the productivity of public service like Malaysia. 
- Citizen would be benefited if the services conducted by different departments of the district administration are delivered under the same roof. So government can introduce one-stop shop in DC office.

- Government should take initiatives to increase the internet accessibility of citizens and ensure uninterrupted electricity supply. Like Malaysia, district administration of Bangladesh can launch electric data interchange system, PSN, CSL and different types of web portal.

- DC office can improve the front line service system by introducing counter service approach. Electronic queue management system, one-stop bill payment system, linking counter service computer with the main server to collect data, general information telephone system, indication of expected serving time, customer feedback mechanism, assigning floor manager to address customer need, establishment of CSO, guidebook of handling counter services, deploying efficient employees in the counter services, and giving sufficient training can be done to improve the counter service.

- DC office should be independent in the case of fund raising and fund utilizing, decision making, problem solving, policy making and implementation, making separate DC office manuals, employee's code of conducts and others.

- Independent task force should be established in every ministry of Bangladesh like Malaysia to improve existing systems and procedures, prevent abuse and corruption practices, review the rules and regulations, setting service standard as well as reduce red tape practice in the field administration.

- Every DC office should develop separate manuals of office procedures; correspondence desk files; open office system; procedures of office correspondence and management of meetings.

- Charter approach that has been introduced in DC office should be reviewed and indentify the problems to make it workable.

- The government should take initiative to establish citizen database to get quick information regarding any citizen in delivering services.

- The government should take the opportunity of PPP and engage citizens and voluntary groups in the co-production and improvement of public service. There should be a good coordination between district administration and local government by enacting law describing clearly the division of responsibilities.

- To be more transparent, DC office can take initiatives to publish monthly public paper like the case of Yamaguchi City Hall, where all sorts of service bulletin of the district administration will be given. Effectiveness of the Right to Information Act 2009 should be ensured.

- DC office should introduce digital file disposal system and reduce the number of stages of file movement. Streamlining the process will contribute to the effectiveness of the public service.

- Customers should be given opportunity in choosing channels of getting desired services (internet, mail, face-to-face, telephone or mobile for examples) and establishment of a mechanism of customer helpline is also suggested.

- Benchmarking customer services provided by private sectors can be applied in DC office.

4) DC office should establish a strong customer feedback mechanism by communicating with customer over phone. The gap between customers expected service and perceived service should be identified through a systematic and periodic survey, audit and MIS. Customer complaints should be strictly handled by appointing separate body. Customer experience should be incorporated in the CSAP to update the public service delivery.

5) All the mechanism of public service delivery should be strictly monitored and reviewed. A separate post such as Chief Performance Officer as in the case of the USA, at the rank of ADC level should be created to monitor the performance and service delivery in the district administration. Quality inspection and meeting should be ensured by updating the traditional system.

6) Key performance results should be measured by evaluating output result of people, customer and society. There should be an effort for continuous development of service delivery in DC office, Bangladesh.

\subsection{Conclusion}

The purpose of the study was to identify the learning objectives with the failure modes resolution with the comparison of benchmark framework applied to Bangladesh experience to develop a strategic and tactical systems level framework. Finally, it tries to identify its implication for future practices to ensure effective public service delivery in the field administration of Bangladesh. 
This study shows that public service delivery is an important instrument for boasting up good governance which ultimately contributes to the socio-economic development of a country. However, by applying the benchmark framework and compared with the model developed, it is proved that public sector in Bangladesh is lacking with the effective and quality public service. This condition is very much miserable in the field administration of Bangladesh. Customers are very much dissatisfied with the services received from field administration. As a coordinator as well as pivot of the district administration, DC should play an important role in improving the quality of public service.

The Study also made clear that DC offices are facing the following routine problems: complex file disposal, inefficiency of receipt and dispatch section, non-friendly work station system, non-efficiency in handling electric machineries by employees, unethical practice in performance appraisal system through ACR, outdated rules and regulations, corruptions, centralized administration, lack of prescribed form to apply for services, interference of intermediaries and political pressure, lack of accountability, transparency, motivation and ethical practices.

All these factors induce citizens not to be satisfied with the service received. To remove these problems only a few initiatives such as introduction of Citizen Charter, enactment of Right to Information Act, practice of e-governance, office inspection and monitoring meeting and pilot project for PMS have been taken by DC office. Despite these measures, it is still not sufficient to ensure effective public service delivery.

The proposed framework and model that has been developed through a long journey of literature review, analysis of international experience, case study as well as developing benchmark framework and applying to Bangladesh experience, can be introduced as a better option for reform initiatives in DC office in ensuring effective public service delivery.

The findings of the study have several implications for future research. First, how this strategic and tactical systems level framework and model can be applicable in other public offices of Bangladesh to ensure effective public service delivery; second, how it contributes in boasting up good governance; finally, what will be the result of pre-test and post-test of this strategic and tactical systems level framework and model to improve quality public service delivery in Bangladesh. Those issues will remain for the future attempts to prove the efficiency of the framework and model developed in this study.

\section{References}

Adrienne, C., \& Wilma, L. (2008). Call centre service quality for the public: A Scottish framework for the future. Managing Service Quality, 18(2), 194-208. http://dx.doi.org/10.1108/09604520810859238

Ahmed, S. G. (2002). Public Administration in the Three Decades. In A. M. Chowdhury \& F. Alam (Eds.), Bangladesh: On the Threshold of the Twenty-First Century (pp. 321-354). Dhaka, Asiatic Society of Bangladesh.

Alam, M. S. (1996 \& 1997). Performance Appraisal System of the Bangladesh Civil Service. Bangladesh Journal of Administration and Development, 4(2).

Azizuddin, M. (2008). Public Administration reform in Bangladesh, challenges and prospects. Osder Publication, Dhaka, Bangladesh.

Beer, M., Eisenstat, R. A., \& Spector, B. (1990). Why Change Programs don't produce Change. Harvard Business Review, 158-166.

Gaster, L. (1995). Quality in Public Services. Buckingham: Open University Press.

Hoque, A. N. S. (1982). Sub-national Administration in Bangladesh and its role in Development: An overview. Rajshahi University, Bangladesh.

Humphreys, P. C. (1998). Improving Public Service Delivery. CPMR Discussion Paper No. 7, Dublin: IPA.

Humphreys, P. C., Sile, F., \& Orla, O. (2000). Improving Public Service in Ireland: A case study approach. CPMR Discussion Paper No. 11 Dublin: IPA. Retrieved from http://www.city.yamaguchi.lg.jp/cms-sypher/www/gov/result-jsp?life-genr=310

Jacobs, R. W. (1994). Real Time Strategic Change. San Francisco: Berrett-Koehler Publishers.

Jahan, F. (2006). Public Administration in Bangladesh, Center for Governance Studies. Working Paper.

Karim, M. R. B. A. (1995). Improving the efficiency of the Public Sector: A case study of Malaysia. Consultant to the Department for Development Support and Management Service of the United Nations Secretariat, 5 July 1995. 
Karim, Md. A. (2010). Digital Bangladesh for Good Governance. Prepared for Development forum 2010, Bangabandhu International conference Centre, Dhaka, Bangladesh, pg. 3.

Kristi, M. B. (2002). Change Management.

Lawton, A., \& Rose, A. (1994). Organization and Management in the Public Sector (2nd ed.). London: Pitman.

Luna, M. D. (2002). Fighting Corruption and safeguarding Integrity: A Shared Responsibility Based on Prevention, Transparency and partnership. International Institute of Public Ethics Conference. Brisbane Australia.

Majumdar, Md. N. A. (2005). Civil Service Ethics and Good Governance, Australia and Bangladesh Experience.

Merit System Protection Board. (2006). Report on Designing an Effective Pay for Performance Compensation System. U.S.

Miles, R. H. (1997). Leading Corporate Transformation. San Francisco: Jossey-Bass Publishers.

Mohrman, S. A., \& Allan, M. M. Jr. (1993). Organizational Change and Learning. In Jay R. Galbraith, Edward E. Lawler III (Eds.), Organizing for the Future: The New Logic for Managing Complex Organizations (pp. 87-108). San Francisco: Jossey-Bass Publishers.

Monaem, M., \& Islam, K. N. (1996 \& 1997). Transfer Promotion and Administrative Efficiency of Civil Servants in Bangladesh: an Analysis' Bangladesh. Journal of Administrative and Development, 4(2).

Nadler, D. A., \& Michael, L. T. (1997). Implementing New Designs: Managing Organizational Change. In Michael L. Tushman \& Philip Anderson (Eds.), Managing Strategic Innovation and Change (pp. 595-606). New York: Oxford University Press.

Ninth Malaysia Plan. (2006-2010). Efficient Public Service Delivery System.

Obaidullah, A. T. M. (1999). Bangladesh Public Administration, Study of major reforms, constraints and strategies. Academic press and publishers limited, Dhaka, Bangladesh.

Obaidullah, A. T. M. (2001). Democracy and Good Governance the role of Ombudsman. Bangladesh Institute of Parliamentary studies, Dhaka.

OECD. (1996). Responsive Government: Service Quality initiatives Paris. Organization for Economic co-operation for development.

OECD. (1998a). Emerging Market Economy Forum Workshop on Public Management in Support of Social and Economic Objectives. Session 3- Responding to Citizens-Paris: OECD.

OECD. (2010). Towards recovery and partnership with citizens: The call for innovative and open government: A review of recent initiatives, Ministerial meeting of the OECD public governance committee, 15 November 2010.

Osborne, D., \& Gaebler, T. (1992). Reinventing Government: How the Entrepreneurial Spirit is Transforming the Public Sector. Reading, Mass: Addison-Wesley.

Parasuraman, A., Zeithaml, V. A., \& Berry, L. L. (1985). A Conceptual Model of Service/Quality and Its Implications for Future Research. Journal of Marketing, 63, 41-50. http://dx.doi.org/10.2307/1251430

Pettigrew, A. (1988). Introduction: Researching Strategic Change. In A. Pettigrew (Ed.), The Management of Strategic Change. Oxford: Basil Blackwell.

President Memorandum. (1998). Conversations with America. Whitehouse, Washington: USA.

President, M. (1995). President Memorandum for head of Executive Departments and Agencies: Improving customer service. Washington: White House Office USA.

Rumy, S. N. A. (2006). District Administration in Bangladesh: An Introduction to Chittagong District.

Schlesinger, L. L., \& Heskett, J. L. (1991). Breaking the Cycle of Failure in Services. Sloan Management Review.

Siddiqui, K. (2006). Towards good governance in Bangladesh, Fifty unpleasant essays. University press limited, Dhaka, 2006.

Tamrakar, R. (2010). Impact of citizen charter in service delivery: A case of district administration, Kathmandu.

Transparency International. (2009). Bangladesh Documents Report on the seminars on Corruption in Public Administration. Dhaka, CIRDAP Auditorium, September 2, 1999. 
Transparency International. (2011). Corruption Index. Report 2011.

United Nations Development Program. (2009). Re-conceptualizing Governance. Discussion Paper No. 2. New York.

World Bank. (1989). World Bank Development Report. Washington DC: World Bank.

\section{Notes}

Note 1. Centerlink is a form of one-stop-shop approach implement in Australia. It is one of the Master Program the Department of Human Services (Australia) that delivers services, programs and payments for ten government departments bringing together under one roof.

Note 2. Quality customer Service Initiative or QCSI is a reform initiative taken by Irish Government in 1997 from the recommendation of Delivering Better Government and comprises principles for the delivery of quality customer service to be incorporated in government department/offices action plan.

\section{Copyrights}

Copyright for this article is retained by the author(s), with first publication rights granted to the journal.

This is an open-access article distributed under the terms and conditions of the Creative Commons Attribution license (http://creativecommons.org/licenses/by/3.0/). 